\title{
BIODIESEL FROM THREE MICROALGAE TRANSESTERIFICATION PROCESSES USING DIFFERENT HOMOGENOUS CATALYSTS
}

\author{
Alberto Paulo I. Cercado ${ }^{1 *}$, Florencio C. Ballesteros Jr. ${ }^{2}$, Sergio C. Capareda ${ }^{3}$ \\ ${ }^{1}$ College of Engineering and Architecture, Capiz State University, Roxas City, 5800 Capiz, Philippines \\ ${ }^{2}$ Department of Environmental Engineering, University of the Philippines, Diliman, Quezon City, \\ Philippines \\ ${ }^{3}$ Biological and Agricultural Engineering Department, Texas A\&M University, College Station, \\ Texas 77843, USA
}

(Received: December 2017 / Revised: February 2018 / Accepted: March 2018)

\begin{abstract}
Biodiesel was produced using three different alkali catalysts, namely $\mathrm{KOH}, \mathrm{NaOH}$ and $\mathrm{LiOH}$. The aim of the study was to determine which of these is the most effective as far as Fatty Acid Methyl Ester (FAME) yield is concerned in producing biodiesel from microalgae. Three different transesterification processes were considered; conventional, microwave-assisted and ultrasound-assisted. The study was able to show that $\mathrm{NaOH}$ and $\mathrm{KOH}$ generated far better FAME values compared to $\mathrm{LiOH}$ in all three transesterification processes. The introduction of microwave or ultrasound in the transesterification slightly increased the FAME yield by $5 \%$ and cut the reaction time by $50 \%$. The best FAME yield was attained when the optimum process parameters were a methanol to oil ratio of 12:1; a catalyst load of $2 \%$ for $\mathrm{NaOH}$ and $3 \%$ for $\mathrm{KOH}$; a reaction time of 12 minutes; and a microwave output power rate of 600 watts.
\end{abstract}

Keywords: Biodiesel; Microalgae; Microwave; Transesterification; Ultrasound

\section{INTRODUCTION}

Biodiesel is produced by the transesterification of oils or fats derived from plant matter or animal waste (Bharathiraja et al., 2014), but the use of biodiesel has a potential environmental impact. Global dependence on fossil fuels has resulted in emissions that contribute to global warming (Höök \& Tang, 2013). Petroleum-based fuels lead to the emission of polluting gases such as $\mathrm{CO}_{2}, \mathrm{HC}$, NOx and SOx (Borugadda \& Goud, 2012). In 2008, nearly 30 billion tons of carbon dioxide were produced from fossil fuel use, double that of 1970 (Dai et al., 2014). While fossil fuels only emit $\mathrm{CO}_{2}$, biodiesel or ethanol derived from plants makes use of $\mathrm{CO}_{2}$ in the atmosphere from the plant photosynthesis. Biodiesel produces $41 \%$ fewer Green House Gas (GHG) emissions when compared to diesel (Issariyakul \& Dalai, 2014).

To make biodiesel production more feasible, studies on the transesterification of non-edible oils have been conducted. Microalgae have many advantages compared to other feedstock. Of the $1.46 \times 1011$ tons of biomass produced annually around the world, $40 \%$ is attributed to algal photosynthesis (Cheng et al., 2013). This is because algae have a higher photosynthetic yield (3-8\%) than other plants (less than 1\%), which makes them grow faster (1-3 doublings per day), sequestrate carbon dioxide much better, and accumulate a lipid yield of up to 50\% (Patil et al., 2011). Moreover, algae can grow in arid land, swamps and saline

\footnotetext{
*Corresponding author's email: cercadopaulo@gmail.com, Tel. +63-9772825525

Permalink/DOI: https://doi.org/10.14716/ijtech.v9i4.1145
} 
or fresh water, which means they do not compete for land utilization against others crops, either for fuel or food production (Patil et al., 2011b). However, the problems associated with algae in biodiesel production are in its harvesting, due to its high water content, and in lipid extraction because of its cellular structure (Singh et al., 2014). Given that microalgae have cell walls that minimize a solvent's entrance into the lipids, processes have been developed to harness extraction by weakening the cell walls or even breaking them down. Weakening the cell walls can increase the diffusion of lipids, and breaking them down further releases the remaining lipids within the algal cell membranes. The common processes that assist lipid recovery and biodiesel conversion are the supercritical method, and microwave-assisted and ultrasoundassisted extraction and transesterification (Park et al., 2015). In microwave-assisted extraction and transesterification, microwaves transfer energy into the algae-solvent mixture through dipolar polarization, ionic conduction, and interfacial polarization mechanisms. Heat and pressure will be produced within the mixture, which will force out the lipids from the biological matrix in a shorter amount of time (Patil et al., 2011a). On the other hand, ultrasound induces intense mixing due to the continuous compression and rarefaction cycles, which cause cavitational bubbles (Martinez-Guerra et al., 2014). This generates super-high local temperatures and pressures, thereby increasing the bulk temperature and reactant interaction, and accelerating the reaction (Suganya et al., 2014). These three processes can also be used one after another or even in combination.

\section{MATERIALS AND METHODS}

\subsection{Materials}

The Food Protein Research and Development Center (FPRDC) of Texas A\&M University (TAMU) supplied the dried microalgae (95\% Chlorella Vulgaris). The ultrasonic processor UP400S that was used during the transesterification experiments was a product of Heilscher, USA, while the microwave oven used was a regular commercial oven purchased from Walmart, with maximum output power of 1000 watts. Other materials used in the oil extraction, transesterification and biodiesel analysis were purchased from Sigma Aldrich Chemical Corporation, USA and VWR Chemical Corporation, USA.

\subsection{Transesterification Reaction}

Five hundred grams of dried microalgae was loaded into an extraction thimble, then placed in a Soxhlet extraction set-up. The solvent was n-hexane and the time taken for the whole lipid extraction procedure was 6 hours. The distillate was then transferred to a rotary evaporator to separate the extracted algal oil from n-hexane. The oil was bleached, degummed, and dewaxed according to the procedure described by Tyagi et al. (2012). Five grams of the refined algal oil was then weighed and placed in a $250 \mathrm{ml}$ flask. Methanol and metal loaded pumice were then added to the same flask before being placed in the reaction vessel and then into the microwave oven. The amount of methanol (from 6:1 to 22:1 methanol to oil ratio) and catalysts (1 to 10\% by weight of oil) were varied during each experiment. The conventional transesterification process started as soon as the heating plate was turned on, and the length of the reaction varied between experiments $(5-120 \mathrm{~min})$. In the microwave-assisted transesterification, the time varied from 5-60 mins; output power also varied, from 200 to 1000 watts. In the ultrasoundassisted transesterification, the time varied to the same degree as in the microwave-assisted transesterification, and the percentage of ultrasonic amplitude varied from 10 to $100 \%$. The variations in the process parameters were made to identify their optimum values during the experiments.

After transesterification, the mixture was then placed in a separatory funnel and left to stand for 6 hours. The glycerine that sank to the bottom was removed, and the remaining biodiesel was washed with $20 \%$ hot water by weight to dissolve the soap. The water with dissolved soap 
settled to the bottom of the flask and was drained in the separatory funnel. The remaining product, the biodiesel, was then weighed and a sample was loaded and analyzed by the GC-MS.

\subsection{Analysis}

The fatty acid methyl ester (FAME) composition in the final product was analyzed by GC-MS. The samples were dissolved in dichloromethane in the ratio of 1:4 and placed into the GC tray. Helium was used as the carrier gas and the sample injection volume was $1.0 \mu \mathrm{l}$ at a temperature of $180^{\circ} \mathrm{C}$. The GC-MS temperature program was set at $50^{\circ} \mathrm{C}$, held for 5 minutes, increased to $250^{\circ} \mathrm{C}$ at $5^{\circ} \mathrm{C} / \mathrm{min}$, and then held at $250^{\circ} \mathrm{C}$ for another 10 minutes. Methyl stearate was used as the standard to determine the relative weight composition of the sample. The biodiesel FAME yield was calculated by its weight in the crude biodiesel relative to the weight of oil extracted from the dried microalgae.

\section{RESULTS AND DISCUSSION}

In the conventional transesterification of microalgae using a homogenous catalyst, it was found that the optimum reaction temperature of the mixture was just above $60^{\circ} \mathrm{C}$ (see Figure 1). This was true regardless of the kind of catalyst involved, $\mathrm{LiOH}, \mathrm{KOH}$ or $\mathrm{NaOH}$. The results are in agreement with what is presented in the literature, denoting that the best reaction temperature in the transesterification process is slightly below the boiling point of the reacting alcohol (Singh et al., 2014). Extending the reaction temperature beyond the boiling point of the alcohol lowers the FAME yield of the biodiesel, since the ratio of methanol to oil decreases due to the evaporation of alcohol (Issariyakul \& Dalai, 2014).

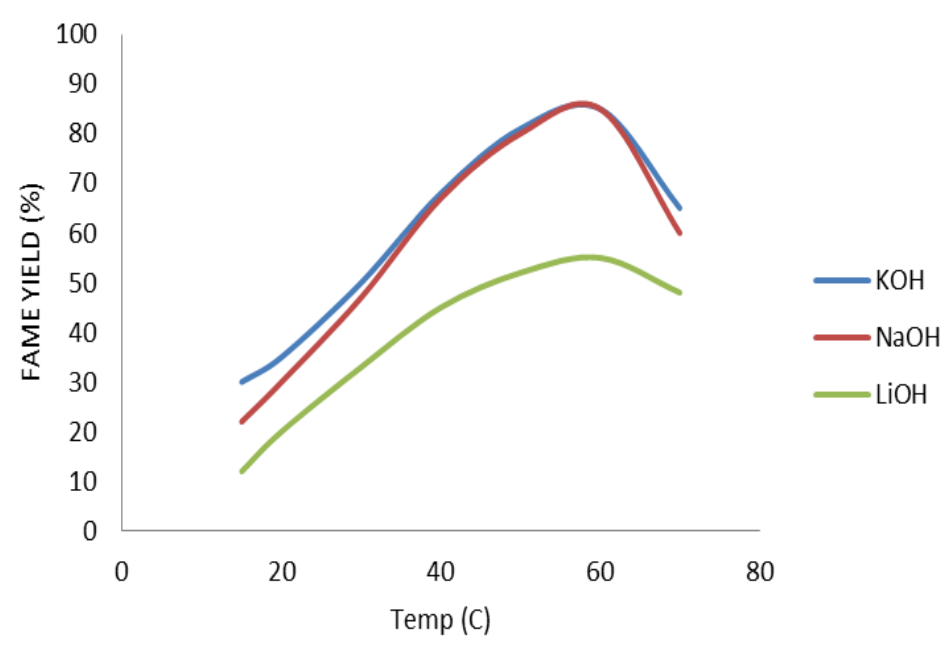

Figure 1 Influence of reaction temperature on FAME yield

As far as reaction time is concerned (Figure 2), the optimum reaction time for all the catalysts selected is 30 minutes. Extending this time beyond the specified figure did not significantly increase the FAME yield of the biodiesel, regardless of the catalyst. The best methanol to oil ratio in the conventional transesterification processes involving any of the three catalysts was 12:1. In order to produce methyl esters, three moles of alcohol are needed to pair with one mole of triglyceride in order to produce three moles of methyl ester. It is noted that since the transesterification reaction is reversible, extra moles of alcohol should be present to suppress the backward reaction. 


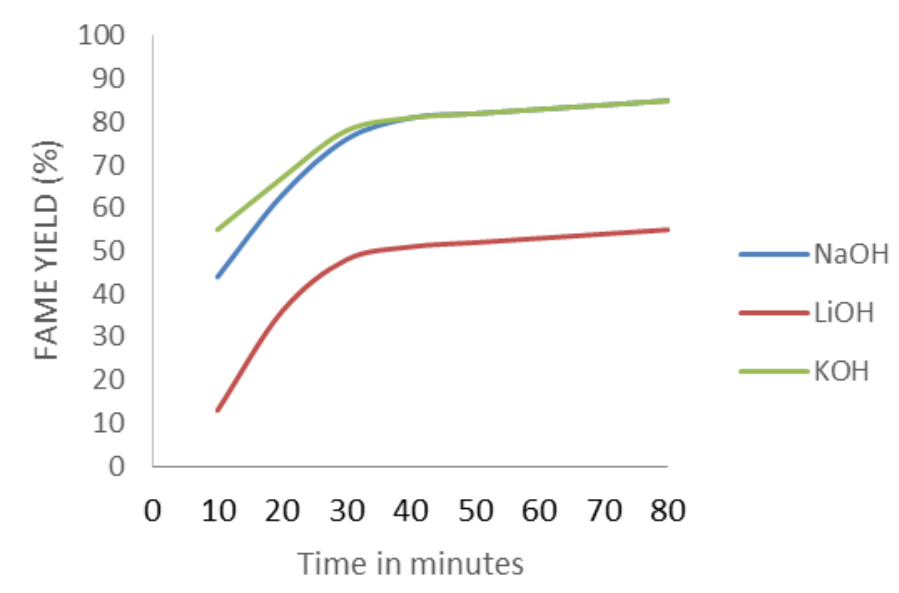

Figure 2 Influence of reaction time on FAME yield

Excessive methanol, however, dilutes the reaction mixture and will not improve the FAME yield of the resulting biodiesel. Moreover, separation of methanol in the resulting biodiesel will be costly and the purity of the glycerine by-product is sacrificed, reducing its market value. The identified optimum catalyst load in the conventional transesterification processes varied depending on the kind of catalyst. In the three homogenous catalysts used in the study, $\mathrm{KOH}$ and $\mathrm{NaOH}$ had almost similar results as far as FAME yield was concerned. Lithium hydroxide, however, did not fare well when compared to the other two. Moreover, LiOH has very low solubility in the reacting alcohol (methanol), which even made the experimental runs very challenging.

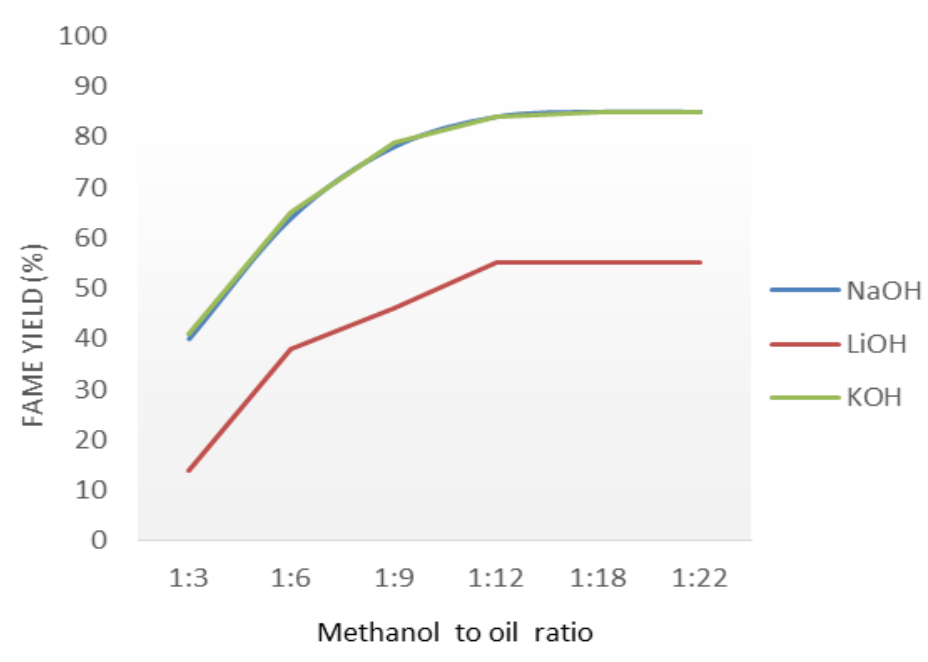

Figure 3 Influence of methanol to oil ratio on FAME yield

As noted in Figure 4, if the catalyst is $\mathrm{NaOH}$ the optimum load is $2 \%$, while it is $3 \%$ for $\mathrm{KOH}$ and $5 \%$ for $\mathrm{LiOH}$. These results are in agreement with past studies involving the use of these catalysts in transesterification experiments. Sodium Hydroxide is most effective in loads from $0.5 \%$ to $2 \%$, while $\mathrm{KOH}$ needs to have a slightly higher load (being a heavier compound) to satisfy the molar ratio. Lithium hydroxide, being a lighter compound, still needed a $5 \%$ catalyst load to obtain the optimum results. This can again be attributed to the low solubility of the compound in the reacting alcohol, thus it needs to have a higher concentration to be more effective. The highest FAME yield attained in the transesterification reaction when the catalyst was $\mathrm{LiOH}$ was just $55 \%$, while it was about $85 \%$ when the catalysts were either $\mathrm{KOH}$ or $\mathrm{NaOH}$. 


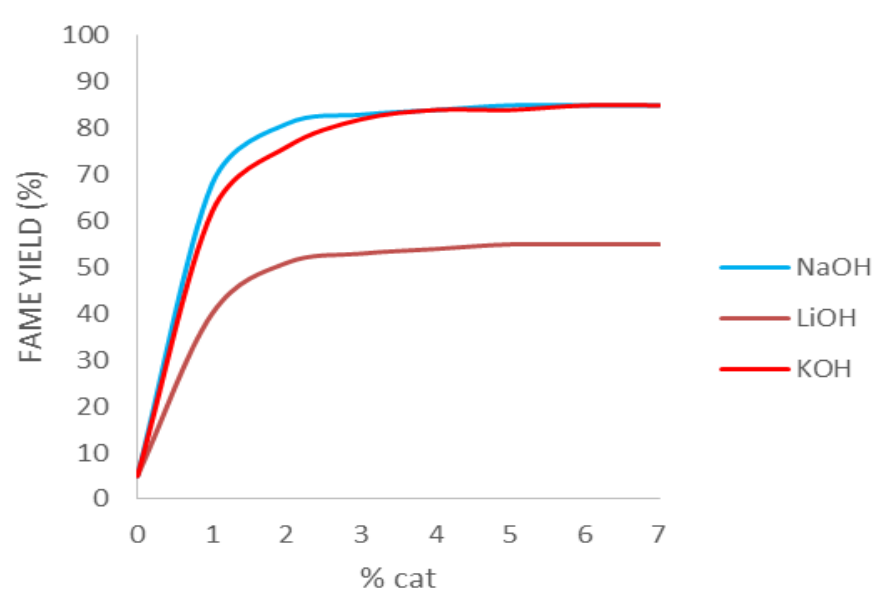

Figure 4 Influence of catalyst loading on FAME yield

When the homogenous catalyst was used in the microwave-assisted transesterification, the optimum parameters that were generated almost mirrored the results that were gathered in the conventional experiments. If the catalyst used was $\mathrm{NaOH}$, the optimum parameters were as follows: methanol to oil ratio 12:1; catalyst load $2 \%$; reaction temperature of $60^{\circ} \mathrm{C}$; and reaction time 12 minutes. The same figures apply if the catalysts are $\mathrm{KOH}$ and $\mathrm{LiOH}$, with only their optimum catalyst loads being different, at 3\% and 5\% respectively. The obvious improvement with the use of the microwaves in the transesterification reaction was that it shortened the reaction time by more than a half (see Figure 5).

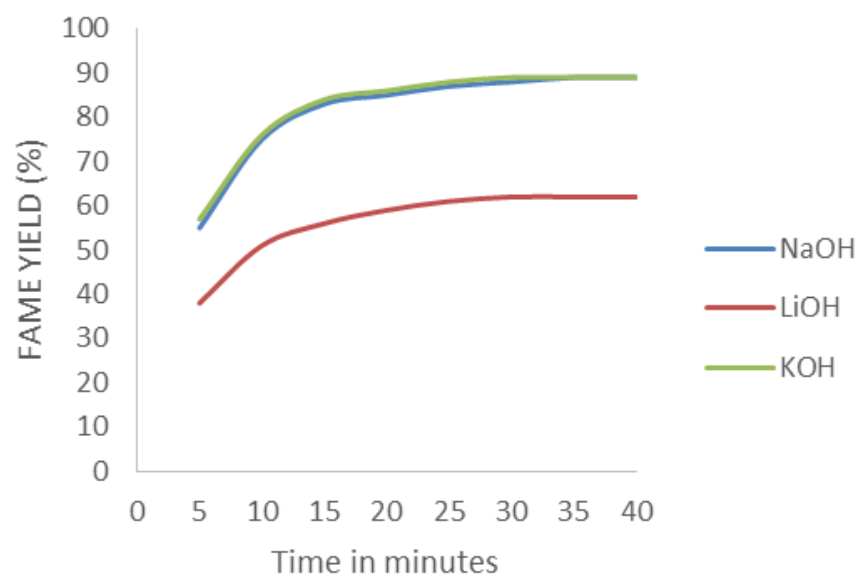

Figure 5 Influence of reaction time on FAME yield in the microwave-assisted transesterification experiments

Microwaves enhanced the reaction by a thermal effect, due to the strong microwave interaction with the materials involved in the reaction. This resulted in a large reduction in activation energy due to the increased dipolar polarization phenomenon. The presence of an $\mathrm{OH}$ group from methanol in the reaction mixture resulted in dipolar rotation and ionic conduction, which resulted in localized superheating, leading to the reaction completing faster. Moreover, the microwave effect in the transesterification experiments not only decreased the reaction time, but also improved the FAME yield of the biodiesel produced by about 3 to 5\% (Table 1). The FAME yields generated with the optimum parameters previously described were $88 \%$ if the catalyst was either $\mathrm{KOH}$ or $\mathrm{NaOH}$, and $60 \%$ if it was $\mathrm{LiOH}$. 
Table 1 Comparison of the FAME yield generated in the conventional, microwave-assisted, and ultrasound-assisted transesterification experiments

\begin{tabular}{lccc}
\hline Catalyst & $\begin{array}{c}\text { Conventional } \\
\text { Transesterification }\end{array}$ & $\begin{array}{c}\text { Microwave-assisted } \\
\text { Transesterification }\end{array}$ & $\begin{array}{c}\text { Ultrasound-assisted } \\
\text { Transesterification }\end{array}$ \\
\hline $\mathrm{KOH}$ & $85 \%$ & $88 \%$ & $88 \%$ \\
$\mathrm{NaOH}$ & $85 \%$ & $88 \%$ & $88 \%$ \\
$\mathrm{KOH}$ & $55 \%$ & $60 \%$ & $60 \%$ \\
\hline
\end{tabular}

The ultrasound-assisted transesterification experiments involving the three catalysts also generated data almost similar to those of the microwave-assisted experiments. The FAME yields when the process parameters were optimized were the same for both processes, showing 3-5\% improvement compared to the conventional transesterification process. In the ultrasoundassisted transesterification of algal oil, it was identified that the optimum methanol to oil ratio was $12: 1$ and that the optimum reaction temperature was $60^{\circ} \mathrm{C}$. Consequently, the optimum catalyst loads for $\mathrm{NaOH}, \mathrm{KOH}$, and $\mathrm{LiOH}$ were $2 \%, 3 \%$, and $5 \%$, respectively. There was, however, a slight difference in the optimum reaction time of the ultrasound-assisted transesterification reaction when compared to that of the microwave-assisted reaction. Both shortened the reaction time, but the ultrasound-assisted transesterification had an optimum reaction time of 15 minutes (Figure 6), while in the microwave-assisted method it was only 12 minutes. The ionic conduction caused by microwave irradiation may have decreased the activation energy far more compared to the mechanism employed by the ultrasonic effect of other technology.

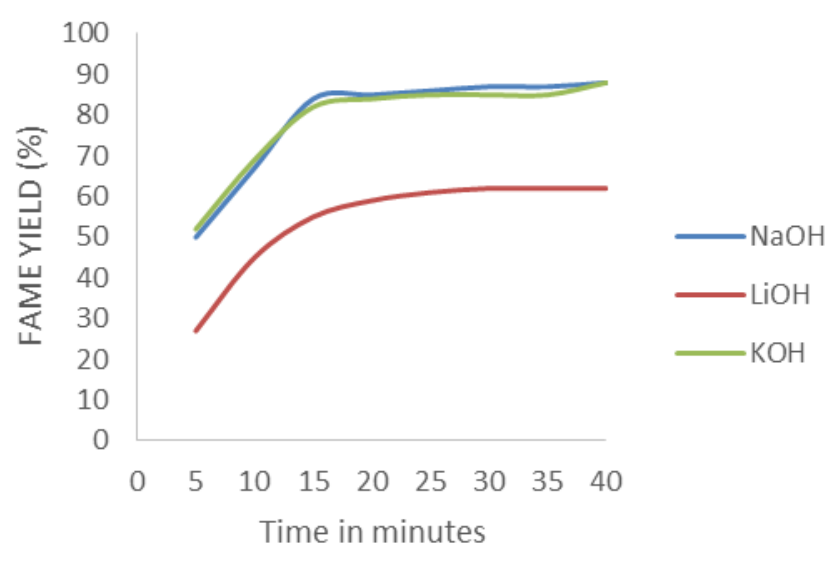

Figure 6 Influence of reaction time on FAME yield in the ultrasound-assisted transesterification experiments using the three homogenous catalysts

\section{CONCLUSION}

The study succeeded in investigating the transesterification processes involving the three homogenous alkali catalysts $\mathrm{NaOH}, \mathrm{KOH}$ and $\mathrm{LiOH}$. Lithium hydroxide was not found to be ideal for the transesterification process due to its low solubility in methanol, therefore producing biodiesel with a low FAME yield of around 55\%. The best performing homogenous catalysts in the conventional transesterification were $\mathrm{NaOH}$ and $\mathrm{KOH}$, with optimum process conditions of a reaction temperature of $60^{\circ} \mathrm{C}$; a methanol to oil ratio of $12: 1$; a reaction time of 30 minutes; and a catalyst load of $2 \%$ for $\mathrm{NaOH}$ and $3 \%$ for $\mathrm{KOH}$. The introduction of microwaves and ultrasound in the conventional transesterification process reduced the reaction time by about $50 \%$ when the catalyst was either $\mathrm{NaOH}$ or $\mathrm{KOH}$, and increased the FAME yield by about $5 \%$ compared to the conventional transesterification process. Optimum output 
microwave power was 600 watts, and optimum ultrasonic percentage amplitude was $40 \%$, producing a FAME yield of up to $88 \%$.

\section{ACKNOWLEDGEMENT}

The authors of the study appreciate the help of friends and staff members of the Bioenergy Testing and Analysis Laboratory (BETA) of the Biological and Agricultural Engineering Department of Texas A\&M University (BAEN-TAMU). The study would not have been possible with their patience and assistance in the use of the materials and faculty equipment. This researchers are also indebted to USAID STRIDE, who funded the whole project.

\section{REFERENCES}

Bharathiraja, B., Chakravarthy, M., Kumar, R.R., Yuvaraj, D., Jayamuthunagai, J., Kumar, R.P., Palani, S., 2014. Biodiesel Production using Chemical and Biological Methods - A Review of Process, Catalyst, Acyl Acceptor, Source and Process Variables. Renewable and Sustainable Energy Reviews, Volume 38, pp. 368-382

Borugadda, V.B., Goud, V.V., 2012. Biodiesel Production from Renewable Feedstocks: Status and Opportunities. Renewable and Sustainable Energy Reviews, Volume 16(7), pp. 47634784

Cheng, J., Yu, T., Li, T., Zhou, J., Cen, K., 2013. Using Wet Microalgae for Direct Biodiesel Production via Microwave Irradiation. Bioresource Technology, Volume 131, pp. 531-535

Dai, Y.-M., Chen, K.-T., Chen, C.-C., 2014. Study of the Microwave Lipid Extraction from Microalgae for Biodiesel Production. Chemical Engineering Journal, Volume 250, pp. 267-273

Höök, M., Tang, X., 2013. Depletion of Fossil Fuels and Anthropogenic Climate Change-A Review. Energy Policy, Volume 52, pp. 797-809

Issariyakul, T., Dalai, A.K., 2014. Biodiesel from Vegetable Oils. Renewable and Sustainable Energy Reviews, Volume 31, pp. 446-471

Martinez-Guerra, E., Gude, V.G., Mondala, A., Holmes, W., Hernandez, R., 2014. Microwave and Ultrasound Enhanced Extractive-transesterification of Algal Lipids. Applied Energy, Volume 129, pp. 354-363

Park, J.-Y., Park, M.S., Lee, Y.C., Yang, J.W., 2015. Advances in Direct Transesterification of Algal Oils from Wet Biomass. Bioresource Technology, Volume 184, pp. 267-275

Patil, P.D., Gude, V.G., Mannarswamy, A., Cooke, P., Munson-McGee, S., Nirmalakhandan, N., Lammers, P., Deng, S., 2011a. Optimization of Microwave-assisted Transesterification of Dry Algal Biomass using Response Surface Methodology. Bioresource Technology, Volume 102(2), pp. 1399-1405

Patil, P.D., Gude, V.G., Mannarswamy, A., Deng, S., Cooke, P., Munson-McGee, S., Rhodes, I., Lammers, I., Nirmalakhandan, N., 2011b. Optimization of Direct Conversion of Wet Algae to Biodiesel under Supercritical Methanol Conditions. Bioresource Technology, Volume 102(1), pp. 118-122

Singh, B., Guldhe, A., Rawat, I., Bux, F., 2014. Towards a Sustainable Approach for Development of Biodiesel from Plant and Microalgae. Renewable and Sustainable Energy Reviews, Volume 29, pp. 216-245

Suganya, T., Kasirajan, R., Renganathan, S., 2014. Ultrasound-enhanced Rapid in Situ Transesterification of Marine Macroalgae Enteromorpha Compressa for Biodiesel Production. Bioresource Technology, Volume 156, pp. 283-290

Tyagi, K., Ansari, M., Tyagi, S., 2012. A novel process for physically refining rice bran oil through degumming. Advances in Applied Science Research, Volume 3, pp. 1435-1439 